\title{
Photoelastic analysis of stress generated by Connecticut Intrusion Arch (CIA)
}

\author{
Alessandro Schwertner ${ }^{1}$, Renato Rodrigues de Almeida², Alcides Gonini Jr33, Marcio Rodrigues de Almeida ${ }^{3}$
}

DOI: http://dx.doi.org/10.1590/2177-6709.22.1.057-064.oar

\begin{abstract}
Objective: The present in vitro study evaluated, by means of the photoelastic technique, the effects generated by the Connecticut Intrusion Arch (CIA), with a $90^{\circ}$ bend on the distal surface of molar tubes and using the $4 \times 2$ appliance on the anterior and posterior regions of the upper dental arch. Methods: Five models were manufactured, in which two different clinical situations were correlated: 1) use of intrusion arch not cinched back and transpalatal bar for anchorage (Group 1);2) use of intrusion arch cinched back and transpalatal bar for anchorage (Group 2). Stress generated in the apical and middle regions of tooth roots of maxillary anterior teeth and maxillary first molars was evaluated. Results: Taking a reference value of $1.0 \mathrm{MPa}=100 \%$, qualitative descriptive analysis was performed, which showed uniformity between stress values in the apical region of anterior teeth of both groups (G1 and G2). In the posterior region, for models with the arch cinched back (G2), stress remained within 100\%. As for G1 models (with the arch not cinched back), variations in the mesial surface of first molars were observed, with an increase of $20 \%$ in the generated stress. The apical region did not undergo any changes, while in the distal region of molars there was a decrease of 20\% in stress. Conclusion: Laboratory results revealed differences in stress between Groups 1 and 2 in the molar region, thereby indicating that there was a tendency towards mesial root tipping of first molars when the distal end of the CIA was not cinched back.
\end{abstract}

Keywords: Intrusion arch. Photoelasticity. Physical properties.

Objetivo: o presente estudo in vitro avaliou, por meio da técnica de fotoelasticidade, os efeitos produzidos pelo Arco de Intrusão de Connecticut (CIA) com dobra de $90^{\circ}$ na face distal dos tubos molares e usando um aparelho $4 \times 2$ nas regiões anterior e posterior da arcada dentária superior. Métodos: foram confeccionados cinco modelos, aos quais foram correlacionadas duas situações clínicas diferentes: 1) uso do arco de intrusão sem dobra distal, mas com barra transpalatina para ancoragem (G1); 2) uso do arco de intrusão com dobra distal e barra transpalatina para ancoragem (G2). Avaliou-se as tensões geradas nos terços apical e médio das raízes dos dentes anterossuperiores e primeiros molares superiores. Resultados: considerando-se um valor de referência de $1,0 \mathrm{MPa}=$ 100\%, foi realizada uma análise descritiva qualitativa, a qual demonstrou uniformidade entre os valores de tensão na região apical dos dentes anteriores nos dois grupos (G1 e G2). Na região posterior dos modelos com arcos com dobra distal (G2), a tensão foi mantida em 100\%. Já nos modelos do G1 (arco sem dobra distal), foram observadas variações na face mesial dos primeiros molares, com um aumento de $20 \%$ na tensão gerada. A região apical não sofreu qualquer alteração, ao passo que, na região distal dos molares, houve uma diminuição de $20 \%$ na tensão. Conclusão: os resultados laboratoriais revelaram diferenças, entre os grupos 1 e 2, para a tensão gerada na região dos molares, indicando que houve uma tendência de mesialização da raiz dos primeiros molares quando não foi realizada a dobra na extremidade distal do CIA.

Palavras-chave: Arco de intrusão. Fotoelasticidade. Propriedades físicas.

${ }^{1}$ Universidad Católica Nuestra Señora de la Asunción (UCA), Department of Orthodontics, Hernandarias, Paraguai-PY.

${ }^{2}$ Universidade de São Paulo (USP), Bauru Dental School, Department of Orthodontics (Bauru/SP, Brazil) and Universidade Norte do Paraná (UNOPAR), Department of Orthodontics (Londrina/PR, Brazil).

${ }^{3}$ Universidade Norte do Paraná (UNOPAR), Department of Dental Materials and Orthodontics (Londrina/PR, Brazil).

Submitted: April 26, 2016 - Revised and accepted: October 14, 2016

\begin{abstract}
How to cite this article: Schwertner A, Almeida RR, Gonini Jr A, Almeida MR. Photoelastic analysis of stress generated by Connecticut Intrusion Arch (CIA). Dental Press J Orthod. 2017 Jan-Feb;22(1):57-64. DOI: http://dx.doi.org/10.1590/2177-6709.22.1.057-064.oar

" The authors report no commercial, proprietary or financial interest in the products or companies described in this article.
\end{abstract}

Contact address: Marcio Rodrigues de Almeida Via Galileu, 1-15, Bauru, São Paulo, Brazil - ZIP: 17053-093

E-mail: marcioralmeida@uol.com.br 


\section{INTRODUCTION}

The $4 \times 2$ appliance is considered a versatile appliance, with easy adaptability and high tolerance for orthodontic treatment in the mixed dentition. In addition to being used for alignment and leveling of maxillary and mandibular incisors, it is used for retraction of incisors in cases of Class II, Division 1 malocclusion, uprighting of incisors in cases of Class II, Division 2 malocclusion, and for minimizing diastemas while gaining space for permanent canines. Also, it assists on correcting the overbite associated with distalization of first molars during application of intrusive mechanics. ${ }^{1,2}$ Overbite correction is one of the greatest challenges faced by orthodontic treatment. ${ }^{3}$ Depending on diagnosis and treatment goals, overbite can be treated with intrusion of mandibular and/or maxillary incisors, extrusion of the posterior segment, or a combination of both. ${ }^{4,5}$

Some of the previous studies on intrusive mechanics have compared different methods for overbite correction,,${ }^{6,7}$ with a few studies employing in vitro ${ }^{8}$ conditions and/or with animals. ${ }^{9}$ One of the methods employed to this end is the utility arch, or a two-couple intrusion arch, which exerts greater moment in the anterior region (counterclockwise intrusive moment) when used in the upper arch. This is also because the caudal angle is located on the mesial surface of the molar tube (resulting in an extrusive effect with a clockwise moment), thus establishing a statically determined system. ${ }^{10,11}$

Cases in which upper intrusive mechanics with a segmented arch is opted for, due to the extrusive force reaction component in the molar region, have a tendency to decrease inter-molar distance $;{ }^{10}$ that is, constriction of the maxilla in the posterior region, a reaction that can be avoided by means of transpalatal bar ${ }^{12}$ or high-pull headgear. ${ }^{5}$

Force exerted for intrusion of anterior teeth should be light and continuous. ${ }^{13,14}$ These characteristics are promoted by alloys such as titanium molybdenum (TMA), and particularly in the Connecticut Intrusion Arch (CIA), which is a nickel-titanium arch with low load-deflection rates, releasing forces ranging from 35 to $45 \mathrm{~g}$, distributed over the four anterior teeth. Importantly, such forces can vary when an intrusion arch is used, depending on the distance between molars and incisors. ${ }^{15}$

Assessment of stress distribution in the periodontium, resulting from the use of an intrusion arch, may be carried out by photoelasticity, a laboratory method that simulates, through photoelastic fringes, the dissipation of strength and movement generated during intrusive mechanics. ${ }^{8,16}$ The applicability of photoelasticity in orthodontic mechanics as an experimental technique, anticipates potential mechanical response resulting from specific efforts. ${ }^{17}$ For this reason, it is a key ally to clinically understand reactions presented by teeth and supporting systems, resulting from the mechanotherapy employed.

The first report on the use of photoelasticity in dentistry was published in 1935, by Zak. ${ }^{18} \mathrm{He}$ investigated orthodontic movements to assess phenomena occurring in the supporting periodontium. To analyze stress and deformation generated in transparent polymers, a polariscope is used. ${ }^{16}$

Photoelasticity has been widely used in Dentistry, especially in Orthodontics, ${ }^{16,19,20}$ Oral and Maxillofacial Surgery, ${ }^{21}$ Restorative Cosmetic Dentistry, ${ }^{22,23}$ Prosthodontics, ${ }^{24}$ Periodontology ${ }^{25}$ and Implantology, ${ }^{26}$ to evaluate occlusion recovery. To this end, models with specific photoelastic resins are manufactured to simulate the effects of mechanotherapy on the structures to be studied.

The applicability of photoelasticity as an experimental technique to study orthodontic mechanics ${ }^{16}$ allows to anticipate the potential mechanical response, either in simulating correction of the curve of Spee, traction of impacted canines by means of reciprocal anchorage or canine retraction by means of loops and elastics. ${ }^{27} \mathrm{~A}$ protocol for manufacturing study models with photoelastic resin was developed for stress analysis during canine retraction using mini-implants anchorage, indicating the feasibility of verifying the results obtained with the photoelastic method simulating supporting structures. ${ }^{16}$

Thus, the aim of this in vitro study was to evaluate the effects of intrusive mechanics on the anterior and posterior regions of the upper dental arch by means of photoelasticity. The null hypothesis was that the use of intrusion arches with or without a $90^{\circ}$ bend (cinched back arch) in the distal surface of maxillary first molars does not imply differences in stress generated in the region of incisors and maxillary molars roots.

\section{MATERIAL AND METHODS Laboratory study}

An upper arch impression was obtained with condensation silicone (Elite Double, Zhermack, USA). A set of artificial teeth (\#11, \#12, \#21, \#22, \#16 and \#26) was re- 
positioned over the impression. The set consisted of crown and root portions, thus creating replicas of natural teeth. With the teeth in place, the entire impression and the root portion of these teeth were covered with colorless, chemically activated acrylic resin (Jet, Clássico Artigos Ordontológicos, Campo Limpo Paulista/SP, Brazil).

After acrylic resin was polymerized and the model was removed, the region of teeth \#13 to \#15 was sectioned vertically with a carborundum disk at low rotation speed, in order to obtain an arch section with the height of the original preserved model $(2 \mathrm{~cm})$. With the aid of a tungsten drill at low rotation speed, buccal and lingual walls were reduced to a minimum width $(1 \mathrm{~cm})$, taking the width of roots in bucco-palatal direction as reference; however, without exposing them. The resulting walls in acrylic resin were finished with sandpaper strips (\#1200 grit) at low rotation speed and polished with a brush, pumice stone and water solution, followed by polishing with a felt disk and a chalk powder-water solution.

Excess polishing material was removed with water. Subsequently, the surface was dried and a standard analysis performed for flaws. A smooth and uniform surface was obtained and no flaws were identified; therefore, a second silicone impression was obtained. This second impression served as reference for the pilot study and also for preparation of the five definitive models made with flexible epoxy resin and hardener (G IV, Polipox, São Paulo, SP, Brazil). ${ }^{8}$ The photoelastic G IV set was mixed in the ratio recommended by the manufacturer $(100: 50 \mathrm{ml})$ in a beaker and with the aid of a glass rod. Subsequently, it was stored at a temperature of $45^{\circ} \mathrm{C}$, to facilitate material homogenization. Resin was then poured into the

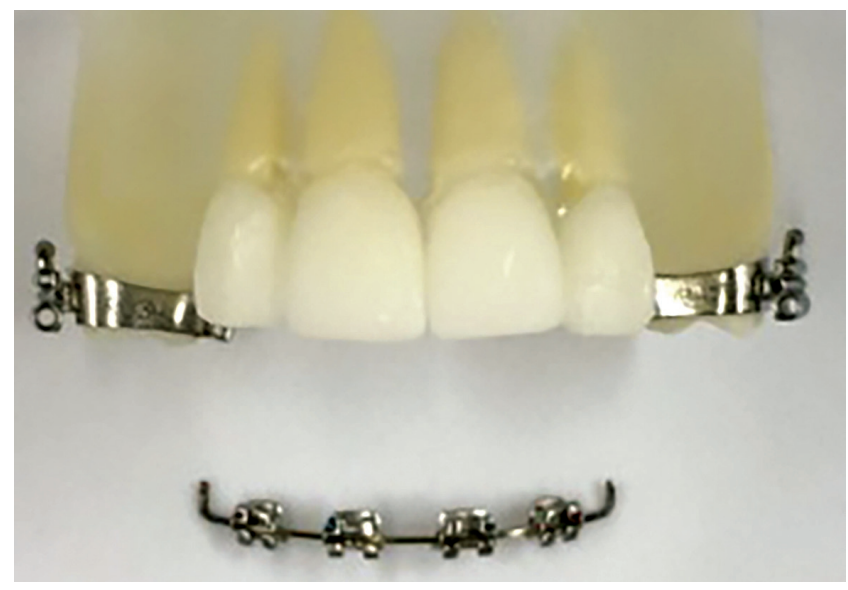

Figure 1 - Brackets previously fixed to a steel wire segment before being passively placed to teeth on the photoelastic model. impressions and remained at rest for 24 hours, after which the photoelastic models were obtained.

Considering the definitive models, bands were placed on upper first molars (Roth prescription/Abzil Lancer$3 \mathrm{M}^{\mathrm{TM}}$, São José do Rio Preto, Brazil), and cemented with glass ionomer (Fuji Ortho LC, GC América Corporation, Tokyo, Japan). Triple tubes (Abzil Lancer$3 \mathrm{M}^{\mathrm{TM}}$, São José do Rio Preto, Brazil) were welded to the bands. For the upper central and lateral incisors, brackets (Kirium, slot 0.022 x0.028-in, Abzil Lancer$3 \mathrm{M}^{\mathrm{TM}}$, São José do Rio Preto, Brazil) were bonded with Super Bonder glue (Loctite, Barueri, Brazil), after being tied to a steel $0.019 \times 0.025$-in arch segment with 0.008 -in ligature wire, so that they could be passively attached to teeth (Fig 1).

Two distinct groups (G1 and G2) were established, each group comprising five independent models. In G1, a long Connecticut Intrusion Arch (CIA, Ortho-Organizers, CA, USA) was placed (Fig 2), previously tied to a steel $0.019 \times 0.025$-in segmented arch in the distal surface of lateral incisors brackets. In the posterior region, the CIA was inserted into the triple tube welded to the band without the arch being cinched back to the tube. Additionally, a passive transpalatal bar was placed as anchorage (Fig 3). In G2, the same procedure was performed, with the intrusion arch cinched back in $90^{\circ}$ at the ends (Fig 4). Since photoelastic material is flexible, a base was manufactured for all models (2-mm crystal plate, Bio-Art Equipamentos Odontológicos Ltda., São Carlos/SP, Brasil) to which they were fixed with Super Bonder glue (Loctite, Barueri, Brazil) in order to avoid potential distortions caused by the intrusion arch (Fig 5).

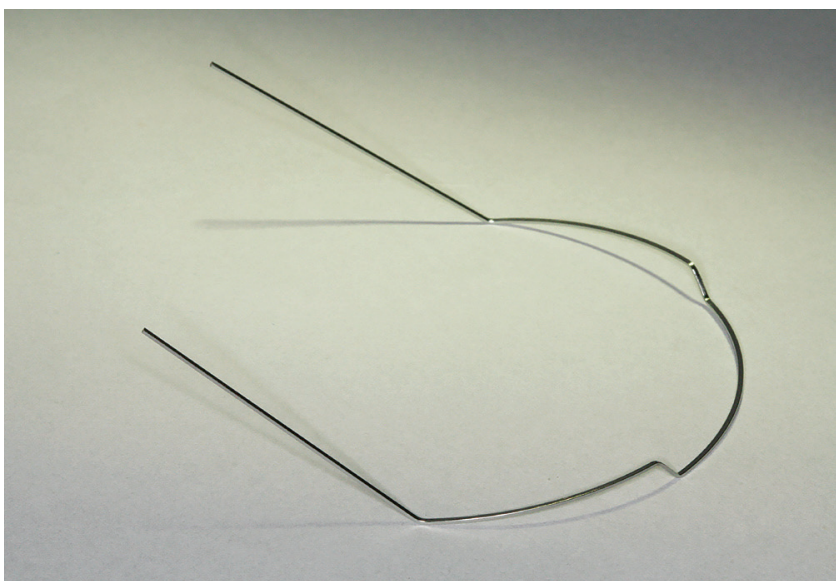

Figure 2 - Upper long $0.017 \times 0.025$-in Connecticut Intrusion Arch (CIA) (Ortho Organizers, Carlsbad, CA, USA). 


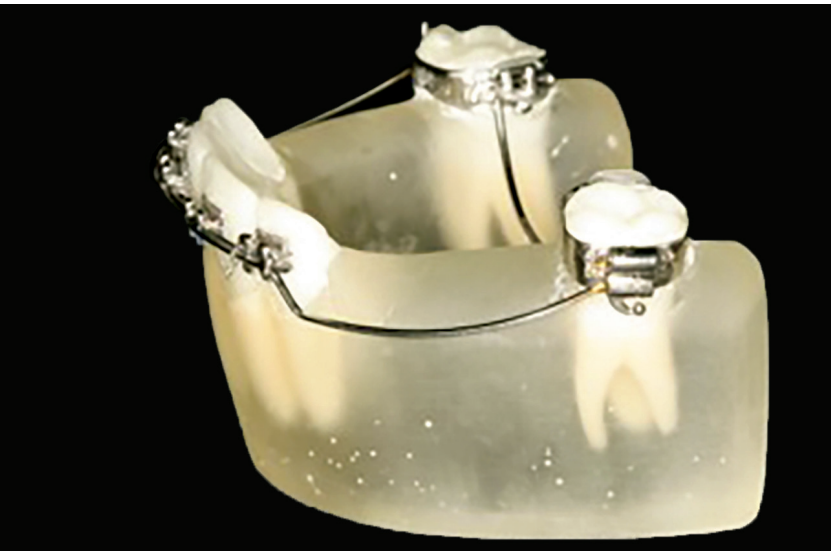

Figure 3 - G1 (with palatal bar and the arch not cinched back).

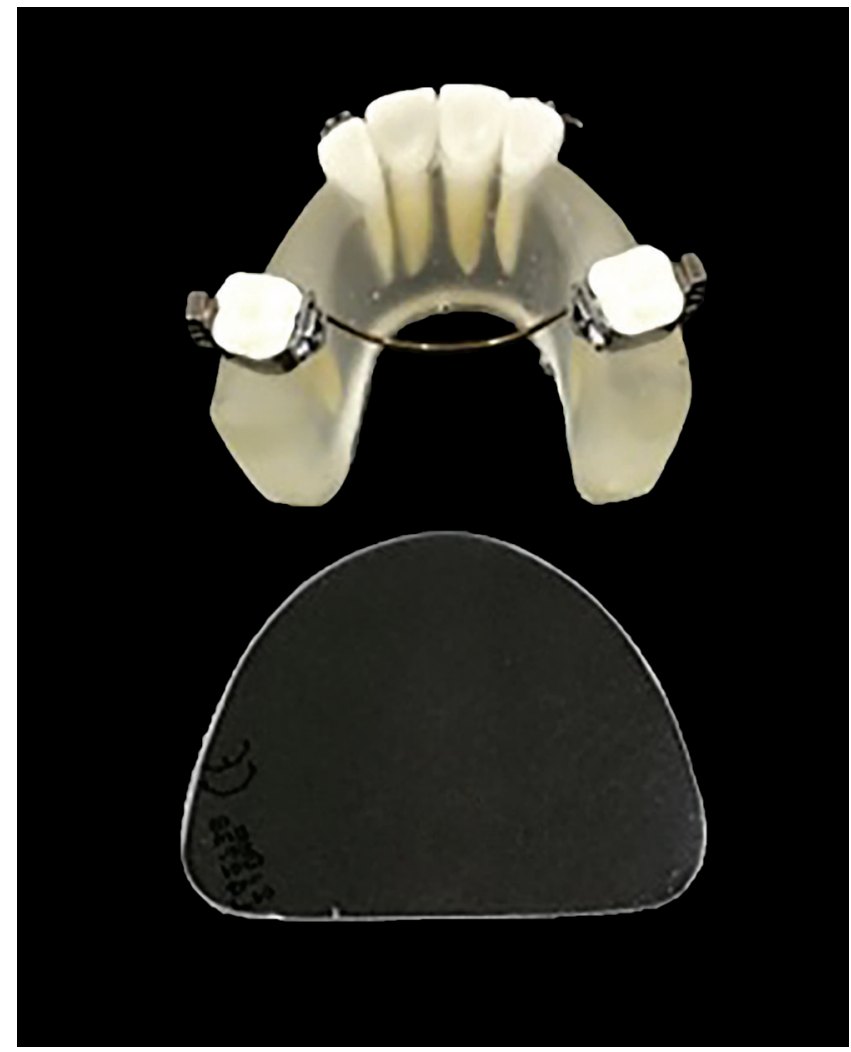

Figure 5 - Crystal model base $(2 \mathrm{~mm}$ ) for fixation and stabilization of photoelastic models.

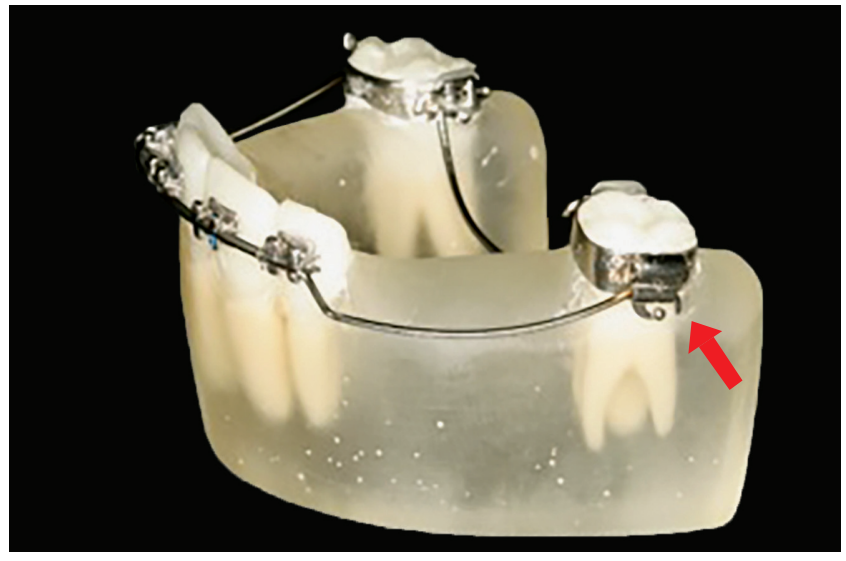

Figure 4 - G2 (with palatal bar and the arch cinched back).

Once the intrusion arch was positioned in each group, stress was automatically generated in the photoelastic model representing the alveolar bone structures. The latter was taken to the front of a reflection polariscope (Vishay LF/Z-2, Malern, USA) which allowed stress evaluation (Fig 6A). Stress was measured at predetermined points around maxillary anterior and posterior teeth, on both left and right sides, which had their root portion split up in the following thirds: $1 \mathrm{~mm}$ of the middle third and $1 \mathrm{~mm}$ of the apical third (Fig 6B). With each test, the stress generated at each point (1 to 8 ) was automatically analyzed by a software (OS CALC 2.0) which converted stress values into megapascals (MPa) (strength divided by area, being $\left.1 \mathrm{MPa}=1.19 \mathrm{kgf} / \mathrm{cm}^{2}\right)$ (Figs 7 and 8$)$.

\section{LABORATORY RESULTS \\ Sample power}

Based on the mean standard deviation obtained in both groups for the eight points $(0.24 \mathrm{MPa})$, adopting an alpha error of 5\% and adjusting for non-parametric tests by means of the Asymptotic Relative Efficiency (ARE) - technique advocated by Randles and Wolfe $^{28}$ - a sample size of $n=5$ in each group presented an $80 \%$ power to detect a minimum difference of 0.6 $\mathrm{MPa}$ among the mean values of groups. 

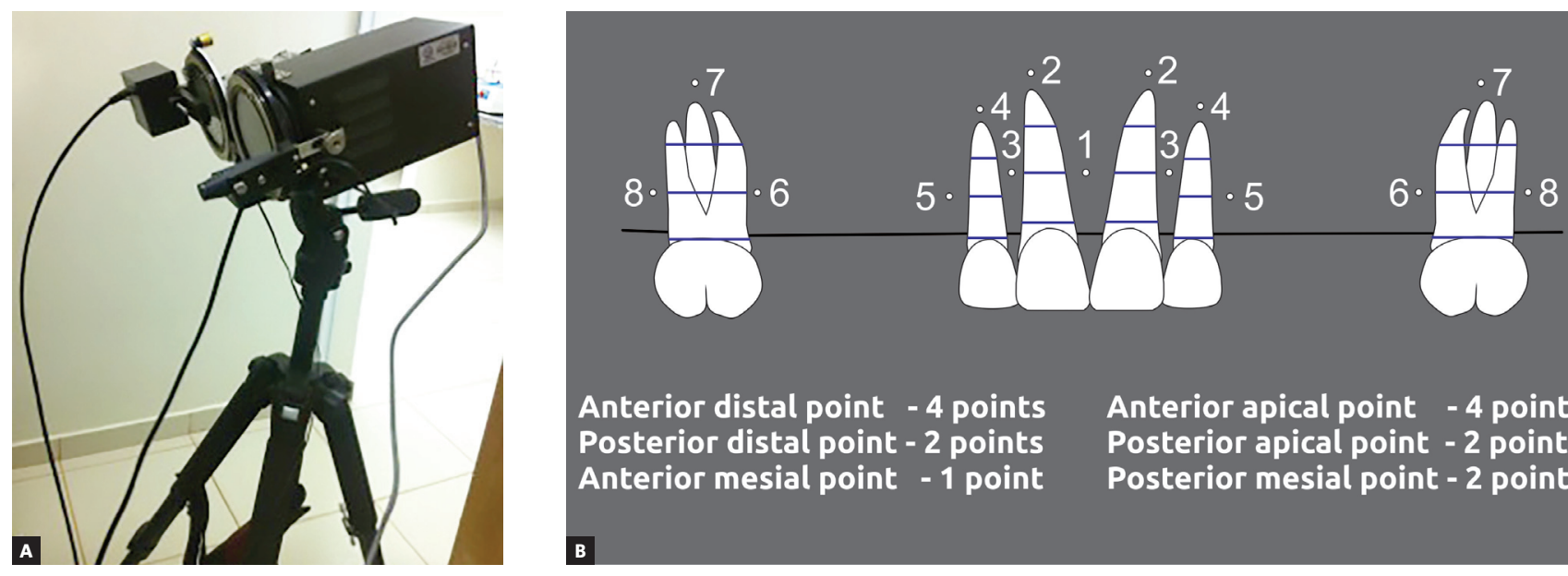

Anterior distal point - 4 points Posterior distal point - 2 points Anterior mesial point - 1 point
Anterior apical point - 4 points Posterior apical point - 2 points Posterior mesial point - 2 points

Figure 6 - A) Reflection polariscope for analysis of stress generated in the photoelastic model. B) Analysis scheme of the middle and apical thirds, bilaterally numbered from mesial to distal.
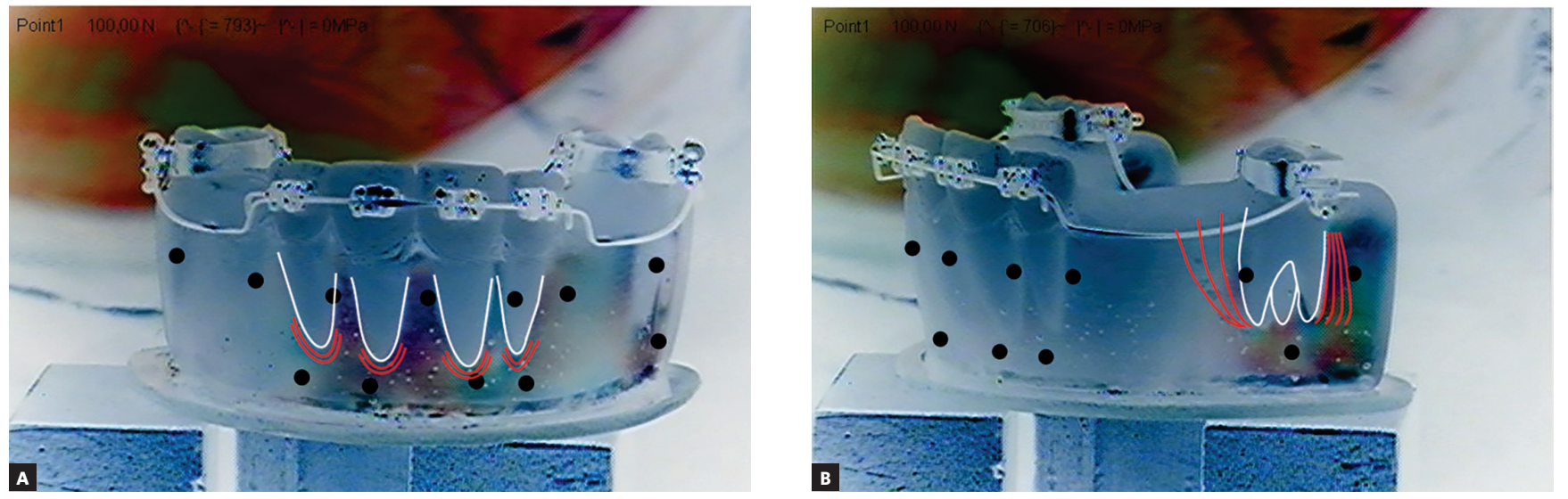

Figure 7 - A) Image of anterior teeth in the polariscope: model with transpalatal bar and without cinching back the intrusion arch (G1). B) Image of molars in the polariscope: model with transpalatal bar, without cinching back the intrusion arch (G1).
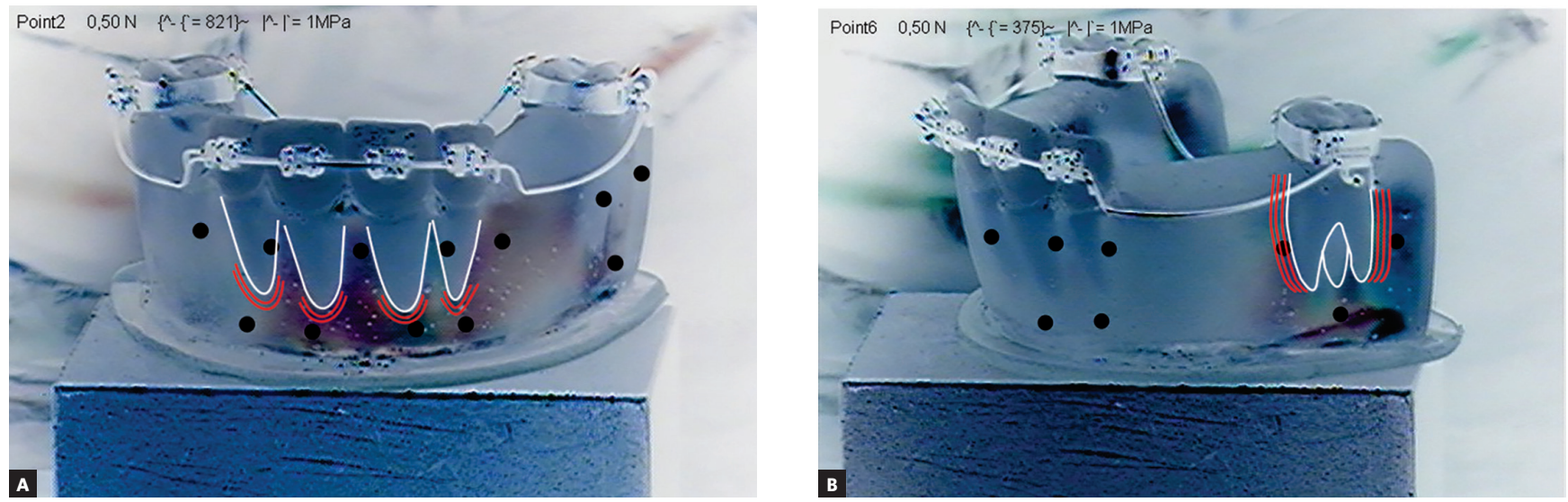

Figure 8 - A) Image of the anterior teeth in the polariscope: model with transpalatal bar and cinching back the intrusion arch (G2). B) Image of molars in the polariscope: model with transpalatal bar and cinching back the intrusion arch (G2). 


\section{WITHOUT DISTAL BEND}

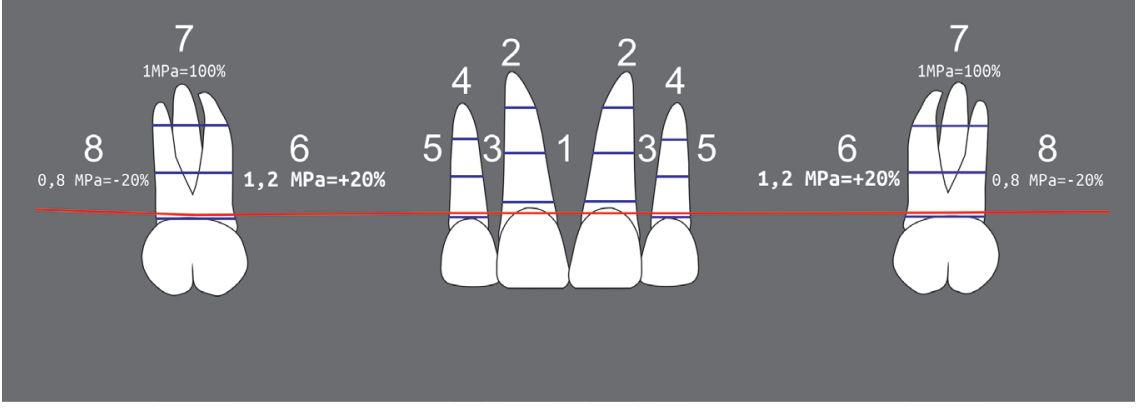

Figure 9 - Scheme illustrating stress generated in the posterior region of G1 group (variation of $\pm 20 \%$ in stress generated between points 6 and 8 ).

WITH DISTAL BEND

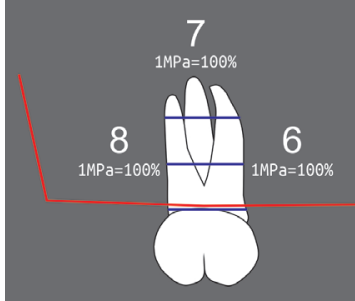

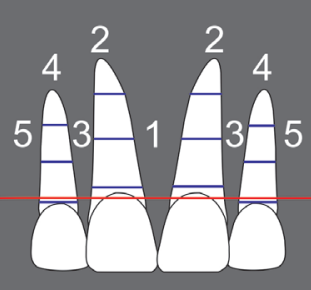

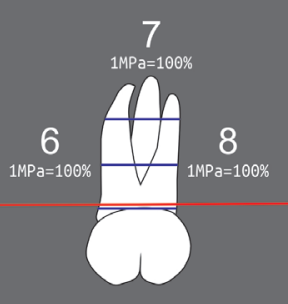

Figure 10 - Scheme illustrating stress generated in the posterior region of G2 group, showing no variation.
Table 1 - Stress generated in the posterior region in the models of both groups.

\begin{tabular}{|c|c|c|}
\hline Model & Points & Tension (MPa) \\
\hline \multirow{3}{*}{ without distal bend } & 6 & $1.2(120 \%)$ \\
\hline & 7 & $1.0(100 \%)$ \\
\hline & 8 & $0.8(80 \%)$ \\
\hline \multirow{3}{*}{ with distal bend } & 6 & $1.0(100 \%)$ \\
\hline & 7 & $1.0(100 \%)$ \\
\hline & 8 & $1.0(100 \%)$ \\
\hline
\end{tabular}

Regarding photoelasticity, a qualitative descriptive analysis was performed taking stress values (MPa) and a reference value of $1.0 \mathrm{MPa}=100 \%$ into consideration, revealing uniformity among stress values in points in the anterior region $(1,2,3,4,5)$ of both $G 1$ and $\mathrm{G} 2$ groups. In the posterior region, particularly at points 6,7 and 8 for models with the arch cinched back, stress remained within a 100\% range. In models of the G1 group (with the arch not cinched back), variations at point 6 , with an increase of $20 \%$ in stress were observed. Point 7 did not show any stress variations, thus remaining at $100 \%$; while at point 8 , there was a decrease of $20 \%$ in stress. Stress values are shown in Table 1 and Figures 9 and 10.

\section{DISCUSSION}

Studies, such as the present research, investigating intrusion and photoelasticity to elucidate the distribution of forces, different mechanics, and root anatomy, are of great importance for orthodontists when evaluating and determining the risk of root resorption for patients. Root resorption is one of the most undesirable effects of orthodontics; therefore, practitioners must always acknowledge it and ensure to take the appropriate measures to avoid it. 
The laboratory methods employed in this study allowed to identify and measure the fringe order in the regions of incisors and maxillary first molars roots, thus enabling statistical analysis of data. Results provided some understanding and comparison of the effects of intrusive mechanics with the CIA intrusion arch, by identifying the areas of greatest stress concentration, which are therefore more prone to tooth movement.

The anatomy of tooth roots influences the distribution of stress generated by orthodontic mechanics, $8,20,29$ whereby anterior intrusion forces can lead to tooth proclination. ${ }^{7}$ However, when they are set along the tooth axis in a photoelasticity ${ }^{20}$ study, they induce the formation of symmetric fringes in the apical region. In this study, despite the greater appearance of fringes created in the apex of lateral incisors when compared to the apex of central incisors, measurement showed no significant differences in stress among the studied groups.

It is relevant noting that any comparison of laboratory results with clinical outcomes should be interpreted with caution, since the photoelastic method does not faithfully reproduce the role played by the periodontal ligament. 8,17 Previous reports mention that intrusive forces are mostly absorbed by cervical and middle thirds when applied to a tooth with tapered root surrounded by photoelastic material. ${ }^{8,30}$ In the present study, only the apical and middle thirds (near the center of resistance in mesiodistal direction) of central incisors, lateral incisors and maxillary first molars were assessed, since no fringes were observed in the cervical third of teeth involved in the pilot study. Once the proposed laboratory model (reproduction of the upper dental arch in mixed dentition) was semi-circular, and the distance from the buccal to the palatine surface of the photoelastic model had an average thickness of $1 \mathrm{~cm}$, it was not possible to assess stress relative to the tendency of incisors to tip or not.

Fringe areas denote stress in the apical region (points 2 and 4), which proves the axial direction of forces resulting from the intrusion arch. In the anterior inter-dental region, there was practically no stress, despite identification of fringes. This is because during the incidence of polariscope light at zero position, fringes can only be seen by refraction of light. However, when the position of light incidence changes, in order to measure stress generation, strength expressed in MPa becomes insignificant.
At point 6 (mesial region of first molars), a larger stress area was found in G1 group when compared to G2 group; while at point 8 (distal region of molars), a smaller stress area was found in G1 group when compared to G2 group; thus proving the moment generated by intrusive mechanics in the molar region, with a tendency towards crown tipping ${ }^{14}$ in G1 group. Since the intrusion arch had its end blocked due to being cinched back, there was an increase in stress in the mesial root of molars (point 6), even with the use of the palatal bar as an anchorage mechanism.

When choosing mechanics for correcting overbite, ${ }^{7,14}$ it is worth determining whether proclination of anterior teeth, distal tipping or molar extrusion are intended. The challenge for the orthodontist lies in cases in which molar relationship is adequate and changing of incisors tipping is undesirable. This study indicates that an intrusion arch cinched back at the posterior region of the arch can be used in cases in which avoiding distal molar tipping is desirable.

Thus, it is recommend that a clinical study employing the same methods be conducted based on the results of this laboratory study, in order to evaluate the effects on anterior and posterior regions when using intrusion arches.

\section{CONCLUSIONS}

" Significant differences between the groups were observed, particularly regarding intrusion arch cinched back in the posterior region. There was a tendency towards first molars mesial roots tipping when the distal portion of the intrusion arch was not cinched back.

" Therefore, having the intrusion arch cinched back is a determining factor for stress generation in the molar region.

" There were no differences between the studied groups regarding apical stress generation in the anterior region. 


\section{REFERENCES}

1. Silva Filho OG, Lara ST, Silva GFB. Nivelamento 4x2: ponderações sobre sua aplicação na dentadura mista e permanente. Rev Clín Ortod Dental Press. 2006:5(3):20-46.

2. Almeida MR. Quando, como e por que utilizar a mecânica 4x2: parte 1. Rev Clín Ortod Dental Press. 2013 Dez-2014 Jan;11(6):10-9.

3. Sreedhar C, Baratam S. Deep overbite: a review (Deep bite, Deep overbite, Excessive overbite). Ann Essen Dent. 2009 July-Sept;1(1):8-25.

4. van Steenbergen E, Burstone CJ, Prahl-Andersen B, Aartman $\mathrm{H}$. The role of a high pull headgear in counteracting side effects from intrusion of the maxillary anterior segment. Angle Orthod. 2004 Aug; 74(4):480-6.

5. Nanda R. The differential diagnosis and treatment of excessive overbite. Dent Clin North Am. 1981 Jan;25(1):69-84.

6. Melsen B, Agerbaek N, Markenstam G. Intrusion of incisors in adult patients with marginal bone loss. Am J Orthod Dentofacial Orthop. 1989 Sept;96(3):232-41.

7. Chiqueto K, Martins DR, Janson G. Effects of accentuated and reversed curve of Spee on apical root resorption. Am J Orthod Dentofacial Orthop. 2008 Feb;133(2):261-8; quiz 328.e2.

8. Claro CAA, Abraão J, Reis SAB, Laganá DC. Stress distribution in a photoelastic model resulting from intrusion of mandibular incisors using Ricketts utility arch Dental Press J Orthod. 2011 Sept-Oct;16(5):89-97

9. Steigman S, Michaeli Y. Experimental intrusion of rat incisors with continuous loads of varying magnitude. Am J Orthod. 1981 Oct;80(4):429-36.

10. Burstone CJ. Deep overbite correction by intrusion. Am J Orthod. 1977 July:72(1):1-22.

11. Janakiraman N, Gill P, Upadhyay M, Nanda R, Uribe F. Response of the maxillary dentition to a statically determinate one-couple system with tip-back mechanics a prospective clinical trial. Angle Orthod. 2016 Jan;86(1):32-8

12. Burstone CJ, Manhartsberger C. Precision lingual arches. Passive applications. J Clin Orthod. 1988 July:22(7):444-51

13. Burstone CJ, Goldberg AJ. Beta titanium: a new orthodontic alloy. Am J Orthod. 1980 Feb;77(2):121-32

14. van Steenbergen E, Burstone CJ, Prahl-Andersen B, Aartman IH. The relation between the point of force application and flaring of the anterior segment. Angle Orthod. 2005 Sept;75(5):730-5

15. Uribe F, Nanda R. Treatment of Class II, Division 2 malocclusion in adults: biomechanical considerations. J Clin Orthod. 2003 Nov;37(11):599-606; quiz 625.

16. Galli LG, Almeida RR, Almeida MR, Conti ACF, Gonini A Jr. Protocolo de confecção de modelos de estudo em resina fotoelástica para análise de tensões durante a retração de caninos com ancoragem em mini-implantes. Ortodontia SPO. 2014:47(1):33-7.
17. Rocha JET, Fuziy A, Tukasan PC, Oliveira RCG. Fotoelasticidade: aplicabilidade na mecânica ortodôntica. Braz Oral Res. 2006;20(Ed. Esp. 1):81

18. Zak B. Photoelastic he analyse in der orthodontics hen mechanik. Zeitschrift Feir Stomatologie. 1935;33:22-37.

19. Hayashi RK, Chaconas SJ, Caputo AA. Effects of force direction on supporting bone during tooth movement. J Am Dent Assoc. 1975 May:90(5):1012-7.

20. Dobranszki A, Vuolo JH, Neto FL, Suzuki H, Barbosa JA, Dobranszki NP. Estudo fotoelástico do controle vertical com o arco de dupla chave na técnica Straight Wire. Rev Dental Press Ortod Ortop Facial. 2009 Jul-Ago;14(4):123-8.

21. Kárász I, Köröndi L, Szabó G. Photoelastic stress analysis on mandibula osteosynthesis. Int J Oral Maxillofac Surg. 1986 June:15(3):259-62.

22. Ernst CP, Kürschner R, Rippin G, Willershausen B. Stress reduction in resinbased composites cured with a two-step light-curing unit. Am J Dent. 2000 Apr:13(2):69-72

23. Lopes MB, Valarini N, Moura SK, Guiraldo RD, Gonini Júnior A. Photoelastic analysis of stress generated by a silorane-based restoration system. Braz Oral Res. 2011 July-Aug;25(4):302-6.

24. Kratochvil FJ, Thompson WD, Caputo AA. Photoelastic analysis of stress patterns on teeth and bone with attachment retainers for removable partial dentures. J Prosthet Dent. 1981 July:46(1):21-8

25. Glickman I, Roeber FW, Brion M, Pameijer JH. Photoelastic analysis of internal stresses in the periodontium created by occlusal forces. J Periodontol. 1970 Jan; 41(1):30-5

26. Gross MD, Nissan J, Samuel R. Stress distribution around maxillary implants in anatomic photoelastic models of varying geometry. Part I. JProsthet Dent. 2001 May:85(5):442-9

27. Rocha JET, Fuziy A, Tukasan PC, Oliveira RCG. Fotoelasticidade: aplicabilidade na mecânica ortodôntica. Braz Oral Res. 2006;20(Ed. Esp.1):81.

28. Randles RH, Wolfe DA. Introduction to the theory of nonparametric statistics. New York: John Wiley and Sons; 1979. 405 p

29. Ng J, Major PW, Heo G, Flores-Mir C. True incisor intrusion attained during orthodontic treatment: a systematic review and meta-analysis. Am J Orthod Dentofacial Orthop. 2005 Aug:128(2):212-9.

30. Maia LG, Maia MLM, Monini AC, Vianna AP, Gandini LG Jr. Photoelastic analysis of forces generated by T-loop springs made with stainless steel or titaniummolybdenum alloy. Am J Orthod Dentofacial Orthop. 2011 Sept;140(3):e123-8. 